\title{
New Record of Leptoglossus zonatus (Dallas) (Heteroptera: Coreidae) Attacking Starfruit (Averrhoa carambola L.) in Sinop, Mato Grosso, Brazil
}

\author{
Evaldo Martins Pires ${ }^{\circledR}{ }^{\bowtie}$, Solange Maria Bonaldo1 ${ }^{1}$, João Alfredo Marinho Ferreira², \\ Marcus Alvarenga Soares ${ }^{3}$ \& Selami Candan 4
}

1. Universidade Federal de Mato Grosso, e-mail: evaldo.pires@gmail.com (Autor para correspondência ${ }^{\bowtie}$ ), smbonaldo@gmail.com. 2. Universidade Federal de Viçosa, e-mail: jamferreira@globo.com. 3. Universidade Estadual de Minas Gerais, e-mail: marcusasoares@yahoo.com.br, 4. Gazi University - Turkey, e-mail: scandan@gazi.edu.tr

EntomoBrasilis 4 (1): 33-35 (2011)

Abstract. Leptoglossus zonatus (Dallas) (Heteroptera: Coreidae) is a phytophagous bug widely found in the American continent. This species is associated with different crops, which they use to establish due to the favorable food supply and conditions for their development. The aim of this work was to record the occurrence of $L$. zonatus attacking starfruit in Sinop, Mato Grosso, Brazil and report a new host plant to this bug species. Adults and immatures were found between September and November of 2009 feeding on starfruit (Averrhoa carambola L.) in Sinop, Mato Grosso, Brazil. The attack affected the fruit quality, allowing other insects, such as some Phoridae species, to access to the fruit secretions through the hole made by the rostrum of this bug and then causing damage to the quality of the fruit.

Keywords: Pest; starfuit; true bug

\section{Novo Registro de Leptoglossus zonatus (Dallas) (Heteroptera: Coreidae) Atacando Frutos de carambola (Averrhoa carambola L.) em Sinop, Mato Grosso, Brasil}

Resumo. Leptoglossus zonatus (Dallas) (Heteroptera: Coreidae) um percevejo fitófago amplamente encontrado no continente Americano. Essa espécie encontra-se associada a diversas culturas agrícolas, onde se estabelecem devido a oferta de alimento e de condições favoráveis ao seu desenvolvimento. O objetivo foi registrar a ocorrência de L. zonatus atacando frutos de carambola em Sinop, Mato Grosso, Brasil e relatar nova planta hospedeira para esse percevejo. Adultos e imaturos foram encontrados durante os meses de setembro a novembro de 2009, atacando frutos de carambola (Averrhoa carambola L.) no município de Sinop, Mato Grosso, Brasil. O ataque desse percevejo prejudica a qualidade dos frutos, permitindo que outros insetos como dípteros da família Phoridae tenham acesso a secreções do fruto pelo orifício feito pelo estilete desse percevejo, causando assim, danos na qualidade da carambola.

Palavras-chave: Carambola; percevejo; praga

$\boldsymbol{L}$ eptoglossus zonatus (Dallas) (Heteroptera: Coreidae) is a species of coreid bug usually found in southest of United States of America, Mexico and Central and South America (Allen 1969; Schaefer \& Panizzi 2000; Henne et al. 2003). This species is related damaging different plants such as cotton (Gossypium hirsutum L.), egg plant (Sonalum melogena L.), citrus (Citrus spp.), bean (Phaseolus vulgaris L.), guava (Psidium guajava L.), passion fruit (Passiflora edulis Sims), water melon (Citrullus lanatus (Thunb.) Matsum. \& Nakai. ), melon (Cucumis melo L.), corn (Zea mays L.), peach (Prunus persica) (L.) Batsch), pomegranate (Punica granatum L.), soybean (Glycine max L.), sorghum (Sorghum bicolor (L.) Moench), tomato (Lycopersicon esculentum Mill. (Silva et al. 1968; Allen 1969; Albrigo \& Bullock 1977; Solomon \& Froeschner 1981; Panizzi 1989; Kubo \& Batista 1992; Zucchi et al. 1993; Rodrigues NetTo \& Gullherm 1996; Matrangolo \& Waquil 1994; Raga et al. 1995; Johnson \& Allain 1998; Schaefer \& PANIZZi 2000; XiaO \& FADAmiro 2009) and also Chilopsis linearis (Cav.) Sweet, Gossypion spp., Phoenix dactylifera L., Sida spp., Spathodea campanulata P.Beauv. and Trinfetta spp. (Silva et al. 1968; Allen 1969; Solomon \& Froeschner 1981; Schaefer \& Mitchell 1983; Souza \& AmARAL-FilHo 1999). Then, the aim of this work was to record the occurence of $L$. zonatus attacking starfruit in Sinop, Mato Grosso, Brazil and report a new host plant to this bug species.

Adults and immatures of $L$. zonatus were found in the Municipality of Sinop, Mato Grosso State, Brazil (Latitude S $11^{\circ}$ 53 ' 101" and Longitude W $55^{\circ}$ 29' $766^{\prime \prime}$ ) between September and
November of 2009 feeding on starfruit (Averrhoa carambola L.) fruits and plants (Figure 1 A, B and C). The records presented in this work were obtained from daily observations of $L$. zonatus feeding on starfruits during the maturation of the fruits between September and November The attack of this species damages the fruit and decreases the its quality. This occurs because this coreidae inserts its stylet for feeding and causes damages on the fruit surface. Also, this behaviour lets other insects, such as Phoridae species, to attack the fruits through the feeding hole of $L$. zonatus that together with its salivary content (digestive enzymes present during the extra-oral process of Heteroptera) (CoHen 1990; 1993; 1995) may become the fruit not viable to be used because of the putrefaction (brown area) and decrease of the consistency on the attacked region (soft area) (Figure 1 D).

Comparing the period of the occurrence of $L$. zonatus in the field, without period of maize plants (the main host plant) and soybean (alternative host plant) in Sinop - MT (September to November) it is possible to hypothesize that the occurrence of this insect species on starfruit plants is associated with foraging for alternative plants to overcome the shortage of food because previous research has shown that this insect behavior using alternative plants to overcome the off-season maize (PANIZZI 1989). The fact that $L$. zonatus seek other plants during the period without maize may contribute to overlapping generations throughout the year, significantly increasing the populations of this insect in corn harvest periods. 

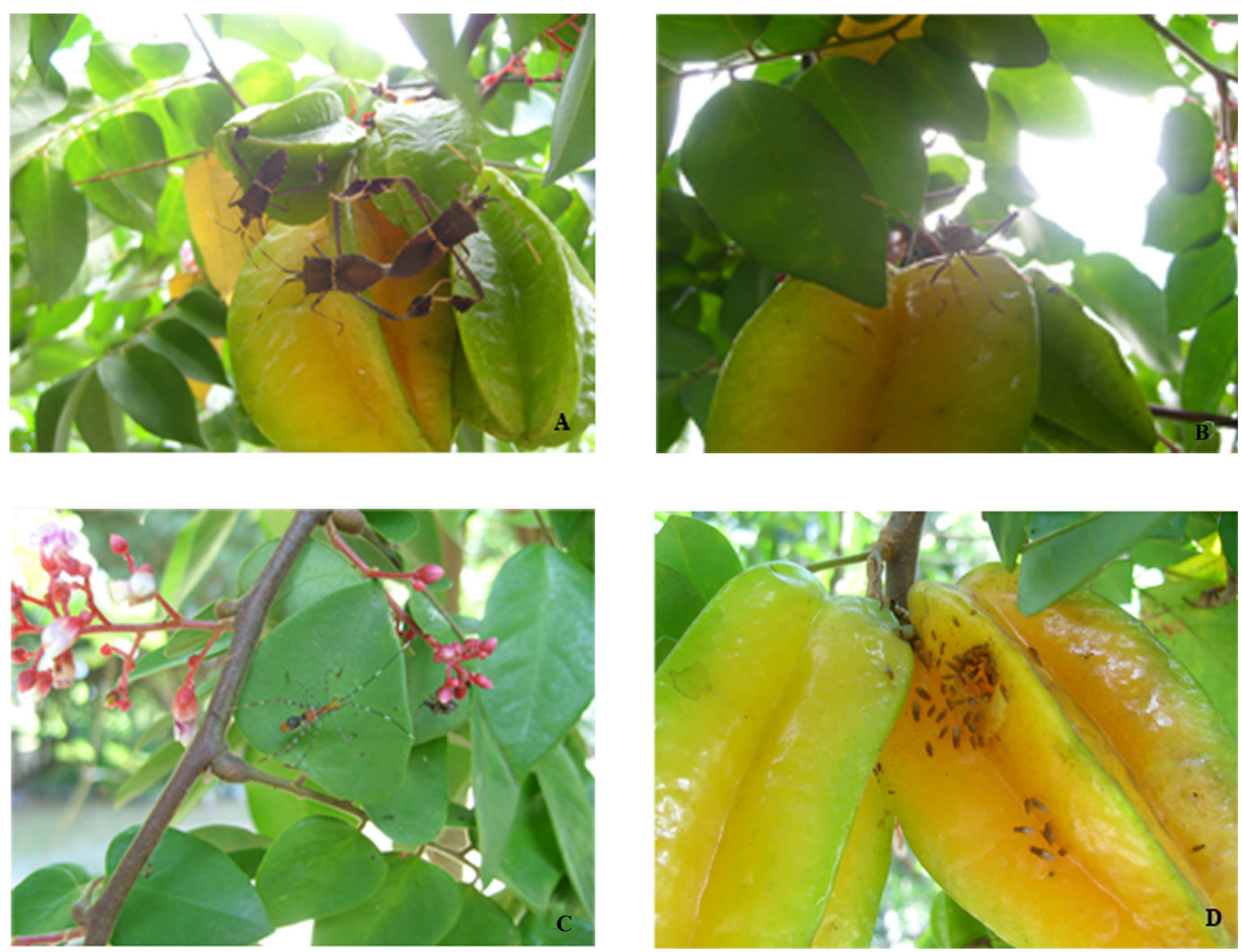

Figure 1. (A and B) Adults and (C) nymphs of Leptoglossus zonatus (Heteroptera: Coreidae) on Averrhoa carambola (Oxalidaceae) plants and fruits. (D) Phoridae species attacking A. carambola (Oxalidaceae) fruits through the damage made by Leptoglossus zonatus in Sinop, Mato Grosso State, Brazil.

\section{REFERENCES}

Albrigo, L.G. \& R.C. Bullock, 1977. Injury to citrus fruit by leaffooted and citrus plant bugs. Proceedings of the Florida State Horticultural Society, 90: 63-67.

Allen, R.C., 1969. A revision of the Genus Leptoglossus Guerin (Hemiptera: Coreidae). Entomologica Americana, 45: 35140 .

Cohen, A.C., 1990. Feeding adaptations of some predatory hemiptera. Annals of the Entomological Society of America, 83: $1215-1223$.

Cohen, A.C., 1993. Organization of digestion and preliminary characterization of salivary trypsine-like enzimes in a predaceous heteropteran Zelus renardii. Journal of Insect Physiology, 39: 823-829.

Cohen, A.C., 1995. Rewiew: Extra-oral disgestion in predaceous terrestrial arthropoda. Annual of Review Entomology, 40: 85-103.

Henne, D.C., S.J. Johnson \& W.J. Bourgeois, 2003. Pest status of leaf-footed bugs (Heteroptera: Coreidae) on citrus in Louisiana. Proceedings of the Annual Meeting of the Florida State Horticultural Society, 116: 240-241.

Johnson, S.R. \& L.K. Allain, 1998. Observations on insect use of Chinese tallow (Sapium sebiferum (L.) Roxb.) in Louisiana and Texas. Castanea, 63: 188-189.

Kubo, R.K. \& F.A. Batista, 1992. Ocorrência e danos provocados por Leptoglossus zonatus (Dallas, 1852) (Hemiptera, Coreidae) em citros. Anais da Sociedade Entomológica do Brasil, 21: 467-470.
Matrangolo, W.J.R. \& J.M. Waquil, 1994. Biology of Leptoglossus zonatus (Dallas) (Hemiptera: Coreidae) fed on maize and sorghum. Anais da Sociedade Entomológica do Brasil, 23: $419-423$.

Panizzi, A.R., 1989. Desempenho de ninfas e adultos de Leptoglossus zonatus Dallas (Hemiptera: Coreidae) em diferentes alimentos. Anais da Sociedade Entomológica do Brasil, 18: 375-389.

Raga, A.C., J. Piza, \& M.F. Souza Filho, 1995. Ocorrência e danos de Leptoglossus zonatus (Dallas) (Heteroptera: Coreidae) em Romã, Punica granatum L., em Campinas, São Paulo. Anais da Sociedade Entomológica do Brasil, 24: 183- 185.

Rodrigues Netto, S.M. \& D.J. Guilhem, 1996. Ocorrência de Leptoglossus zonatus (Dallas, 1852) (Hemiptera: Coreidae) em maracujazeiro (Passiflora edulis $f$. flavicarpa). Arquivos do Instituto Biológico, 63: 85-86.

Schaefer, C.W. \&. P.L. Mitchell, 1983. Food plants of the Coreoidea (Hemiptera: Heteroptera). Annals of the Entomological Society of America, 76: 591-615.

Schaefer, C.W. \& A.R. Panizzi, 2000. Heteroptera of economic importance. CRC Press, Boca Raton, Florida, USA, 828p.

Silva, A.G.A., C.R. Gonçalves, D.M. Galvão, A.J.L. Gonçalves, J. Gomes, M.N. Silva, \& L. Simoni, 1968. Quarto catalógo dos insetos que vivem nas plantas do Brasil. Seus parasitos e predadores. Parte 2, Tomo $1^{\circ}$, Rio de Janeiro, Ministério da Agricultura, $622 \mathrm{p}$.

Solomon, J.C. \& R.C. Froeschner, 1981. Notes on food resources and behavior of the family Coreidae (Hemiptera) in a semideciduous tropical forest. Proceedings of the Entomological 
Society of Washington, 83: 428-431.

Souza, C.E.P. \& B.F. Amaral Filho, 1999. Nova planta hospedeira de Leptoglossus zonatus (Dallas) (Heteroptera: Coreidae). Anais da Sociedade Entomológica do Brasil, 28: 753-756.

Xiao, Y. \& H.Y. Fadamiro, 2009. Host preference and development of Leptoglossus zonatus (Hemiptera: Coreidae) on satsuma mandarin. Journal of Economic Entomology, 102: 19081914.

\section{Como citar este artigo:}

E.M. Pires, S.M. Bonaldo, J.A.M. Ferreira, M.A. Soares \& S. Candan, 2011. New Record of Leptoglossus zonatus (Dallas)

(Heteroptera: Coreidae) Attacking Starfruit (Averrhoa carambola L.) in Sinop, Mato Grosso, Brazil. EntomoBrasilis, 4(1): 33-35. www.periodico.ebras.bio.br/ojs
Zucchi, R.A., S.S. Neto \& O. Nakano, 1993. Guia de identificação de pragas agrícolas. Piracicaba: FEALQ, 139p.

Recebido em: 28/08/2010

Aceito em: 04/11/2010

$* * * * * * * * * * * * *$

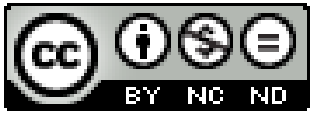

Entomo Brasivis

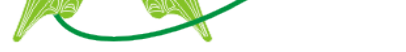

